\title{
Assessment Methods of the Efficiency and Performance of Energy Use in the Public Sphere
}

\author{
Yakupova N. M. ${ }^{1}$, Andreev A. V. ${ }^{1} \&$ Sabitov L. S. ${ }^{1}$ \\ ${ }^{1}$ Kazan Federal University, Institute of Management, Economics and Finance, Kazan, Russia \\ Correspondence: Andreev A. V., Kazan Federal University, Institute of Management, Economics and Finance, \\ Kazan, 420008, Russia. Tel: 7-937-521-3203. E-mail: andreev_leshka@mail.ru
}

Received: December 27, 2014

Accepted: February 19, 2015 Online Published: April 30, 2015

doi:10.5539/ass.v11n11p104

URL: http://dx.doi.org/10.5539/ass.v11n11p104

\begin{abstract}
The paper develops a methodical approach to assessment of the efficiency and performance of energy use in the public sector on the basis of the analysis of normative - legal acts of the Russian Federation and the works of Western and Russian scientists in the field of energy saving and energy efficiency. The paper classifies the indicators characterizing the energy saving and energy efficiency, and identifies those that are most fully and accurately reflect the process of energy saving and energy efficiency, and meet such requirements as objectivity, validity and reliability.
\end{abstract}

Keywords: energy efficiency, energy use indicators, assessment methods, the efficiency and performance of energy use, energy saving

\section{Introduction}

Actual direction of development of modern economy is to increase the efficiency and performance of energy use (Anderson, 2005). Significant contribution to the study of both methodological and practical aspects of the assessment of the level of energy use was made by Western scientists. For example, Shigeru Suehiro, Bent Andersen, Renaud Gicquel, May Gicquel, Xiannuan Lin and Bala Bhaskar identify the GDP energy intensity as a fundamental indicator reflecting the energy efficiency of the economy (Andersen, 2007; Bhaskar, 2013; Gicquel \& Gicquel, 2013; Austria: IAEA, 2005; Lin, 1996; Suehiro, 2007).

Fundamental analysis of the structure of energy consumption in modern society is represented in the works of Nathu Ram Kaswan, Che N., Pham P., Gitana Dudzevičiūtè (Che \& Pham, n. d.; Dudzevičiūtè, 2013; Kaswan, 1992). The study of the parameters of energy consumption (International Energy Outlook 2013 with Projections to 2040) led us to the conclusion that in Russia and in other leading economies of the world the main consumer of energy is the real sector of economy. In addition, it is noted that the public sector is also quite energy intensive (Bashmakov, 2009). Even in countries that show the best examples on the energy intensity of GDP, there is a high energy consumption of the public sector. Thus, in the US a number of educational institutions recognized as energy wasteful (Government Printing Office, 2005; Hu, 2011).

However, it should be noted that unlike the real sector, which mainly consists of private companies, the state doesn't have effective instruments of direct influence on the energy consumption, but may affect the energy consumption of governance public institutions. In this situation, the Russian government has identified the public sector as a demonstration site, which will be the example of the implementation of the energy intensity reducing.

\section{Materials and Methods}

The study was based on normative - legal acts of the Russian Federation in the field of energy saving and research of Western scholars of international agencies such as the International Atomic Energy Agency, United Nations Department of Economic and Social Affairs, International Energy Agency, Eurostat and European Environment agency. The study used scientific methods such as system analysis, synthesis and deduction. Each of these methods was used adequately to its functionality and resolution to solve relevant research tasks.

To assess the level of achievement of the objectives in the field of energy conservation in Russia there is a system of indicators, which is going to be used by the public authorities to carry out a comprehensive approach to information provision of the process of strategic and operational decision-making in the field of energy saving in the public sector of the economy. Conventionally, all these indicators can be divided into the cost, structural 
and relative groups. Cost group includes Russian Federation subject's budget expenditures on ensuring public institutions by the energy resources. Structural group includes the percentage of public and government institutions that have signed energy service contracts in total amount of customers who have signed energy service contracts. Relative group includes specific expenditure of electric power on supplying the state authorities of the Russian Federation subject and the state institutions of the Russian Federation subject.

Our study showed that the assessment of the efficiency and performance of energy use in the public sector of the economy should be based on the use of multidimensional economic values, which are based on the use of multiple indicators. The solution of the problem of multidimensionality of economic values is to select a small number of indicators which are informative and relatively simple in calculation (Yakupova, 2013; Yakupova \& Absalyamova, 2014; Burganova, Novak, \& Salahieva; Azmitov, Ivanovskiy, \& Korabelnikova, 2014).

It is important that these indicators should directly reflect and estimate the analyzed values, not the other properties; should guarantee the possibility of obtaining the same results in repeated measurements and avoid ambiguity in their interpretation. Thus, the indicators should meet the requirements of objectivity, validity, reliability.

Our indicator analysis showed that relative indicators reflect energy saving in the public sector more adequate than others.

On the basis of research on the nature and specificity of the indicators which are used for the monitoring of goals and objectives in the field of energy conservation, we offer four key indicators that reflect energy saving and meet the requirements of objectivity, validity, reliability. There are such indicators as electricity consumption per capita, consumption of water per capita, consumption of natural gas per square meter, consumption of thermal energy per square meter.

The analysis showed that the largest percentage $(80 \%)$ of energy consumption takes heat energy. Specific expenditure of heat in educational institutions of municipalities of Republic of Tatarstan is shown on Figure 1.

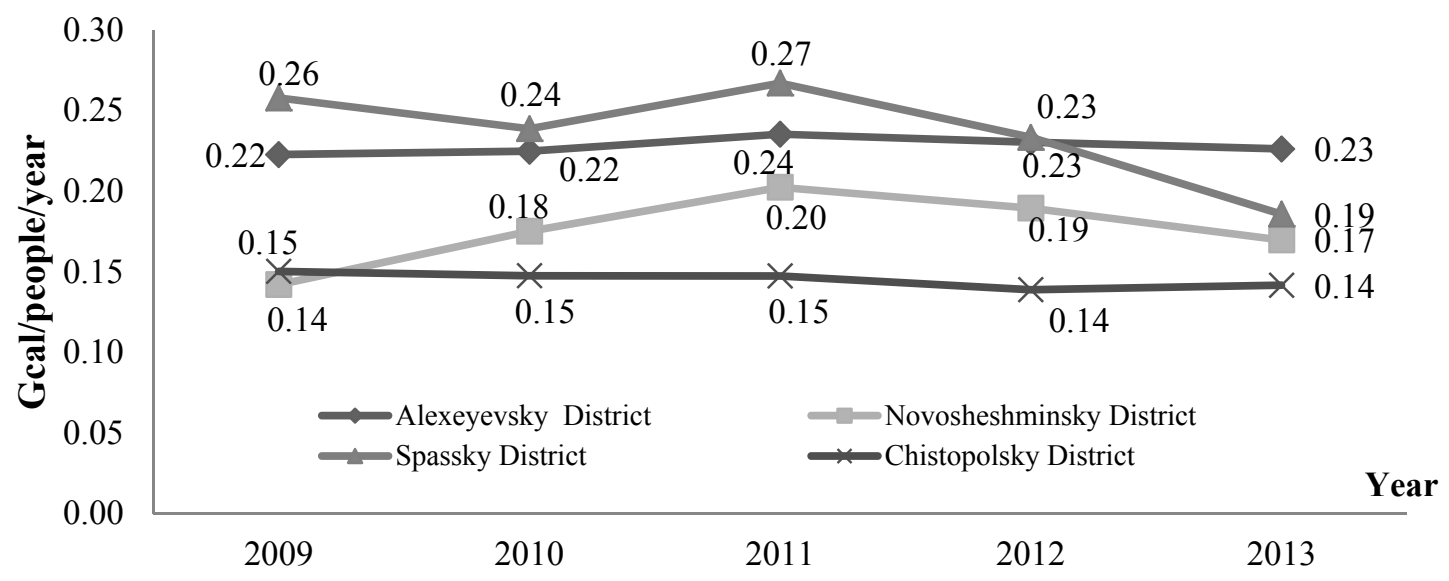

Figure 1. Specific heat consumption of educational organizations in municipal districts of Tatarstan in 2009-2014

Here it is worth to note that the simultaneous analysis of the four indicators leads to some extent complication in evaluation of the efficiency performance of energy use. In these circumstances, there is particularly acute need for an integrated assessment of the efficiency and performance of energy use.

Integral assessment of the efficiency and performance of energy use based on 4 indicators, which were identified earlier, can be made both for specific public institutions and for the public sector in common (education, health, etc.).

We offer to determine integral assessment of the efficiency and performance of energy use on the basis of comparison of achieved energy savings and the corresponding budget spending on energy conservation. In order to achieve a comparable amount of energy consumption their quantitative characteristics must be converted into conventional units - tons of conventional fuel (TCF).

\section{Results}

Method of calculating the economic efficiency of energy use: 


$$
E=\frac{\sum_{i=1}^{n}\left(Q_{i b}-Q_{i e}\right) \times k_{i}}{V}
$$

where: E - the efficiency of energy use,

$\mathrm{Q}_{\mathrm{ib}}$ - the use amount of $\mathrm{i}$-th type of energy source at the beginning of the reporting period,

$\mathrm{Q}_{\mathrm{ie}}$ - the use amount of i-th type of energy source at the finish of the reporting period,

$\mathrm{k}_{\mathrm{i}}$ - coefficient of conversion $\mathrm{i}$-th type of energy source into conventional units (TCF),

$\mathrm{V}$ - budget expenditures on energy conservation,

$\mathrm{n}$ - number of energy source types.

The other indicator that characterizes the degree of achievement of goals and objectives in the field of energy saving in the public sector is the indicator of the performance of energy sources use. As target settings we adopted the standards of consumption of public services institutions. Considering these indicators (standards) as a science - based norms of consumption of certain types of energy, we make the assumption that they reflect the best organizational - technical conditions of the labor and production processes, and the optimal operation of the individual institutions. We should note that these normative standards meet such characteristics as objectivity, validity, reliability; determine the value of the specific energy source consumption; differentiated by type of energy source and budget institutions.

We propose to assess the performance of energy sources use as a measure of the closeness of the actual level of energy use to their normative values. It is assumed that the smaller the deviation of the actual value from the standard, the higher the performance of energy sources use. Integral assessment performance of energy sources use is defined as the weighted average of the percentage of deviation of the specific value of the actual use of energy source from its standard value. We suggest using the share of each type of energy sources in the total energy consumption in conventional units (TCF) as the weights.

Calculation of the share of the i-th type of energy source in the total energy consumption $\left(\mathrm{c}_{\mathrm{i}}\right)$ :

$$
c_{i}=\frac{Q_{i e} \times k_{i}}{\sum_{i}^{n}\left(Q_{i c} \times k_{i}\right)}
$$

Method of calculation of the performance of energy sources use:

$$
R=\sum_{i=1}^{n}\left(\left(\frac{q_{i e}-q_{\text {ist }}}{q_{\text {ist }}}\right) \times c_{i}\right) \times 100 \%
$$

where: $\mathrm{R}$ - the performance of energy sources use,

$\mathrm{q}_{\text {ist }}$ - conventional normative indicator of $i$-th type energy source using,

$\mathrm{q}_{\mathrm{ie}}$ - conventional normative indicator of $\mathrm{i}$-th type energy source using at the finish of the reporting period,

$c_{i}-$ share of $i$-th type of energy source in the total energy consumption.

As an example, we show the results of calculation of the performance of energy sources and cold water in general educational institutions of municipalities of the Republic of Tatarstan. Table 1 shows the performance of the use of heat and electricity in general educational institutions of municipalities of the Russian Federation subject - Republic of Tatarstan.

Table 1. The performance of energy sources use (heat and electricity) in general educational institutions of municipalities of the Republic of Tatarstan (\%)

\begin{tabular}{cccccc}
\hline Municipal District & \multicolumn{5}{c}{ Analyzed period } \\
\cline { 2 - 6 } & 2009 & 2010 & 2011 & 2012 & 2013 \\
\hline Alexeyevsky District & $-1,9$ & $-1,1$ & 4 & 2,5 & 0,3 \\
Novosheshminsky District & $-33,1$ & $-17,8$ & $-5,3$ & $-11,2$ & $-19,6$ \\
Spassky District & 18,5 & 10,3 & 20,6 & 4,2 & $-14,7$ \\
Chistopolsky District & $-53,2$ & $-54,4$ & $-54,8$ & $-58,1$ & $-56,9$ \\
\hline
\end{tabular}


Table 2 demonstrates the performance of cold water use in general educational institutions of municipalities of the Republic of Tatarstan.

Table 2. The performance of cold water use in general educational institutions of municipalities of the Republic of Tatarstan (\%)

\begin{tabular}{cccccc}
\hline Municipal District & \multicolumn{5}{c}{ Analyzed period } \\
\cline { 2 - 5 } & 2009 & 2010 & 2011 & 2012 & 2013 \\
\hline Alexeyevsky District & 79,2 & 70,8 & 33,3 & 58,3 & 95,8 \\
Novosheshminsky District & 280,8 & 277,9 & 110,4 & 29,3 & 63,8 \\
Spassky District & 88 & 44 & 119,4 & 62,1 & 61,7 \\
Chistopolsky District & 163,2 & 70,8 & 72,7 & 61,2 & 52,9 \\
\hline
\end{tabular}

The data in Table 1 and Table 2 shows that many areas have not reached the goals in the field of cold water and energy saving. Thus, the efficiency of energy sources and cold water use reflects not only the characteristics of the use of energy and cold water (normative, ultra normative and economical), but also reflects the level of achievement of the goals and objectives in the field of energy conservation.

We consider it necessary to note that in our view the more appropriate it's to calculate the efficiency of energy use for each type of energy source in the context of individual species of public institutions.

\section{Conclusion}

Thus, in order to ensure regular and continuous provision of analytical information about the efficiency and performance of energy use it is necessary to develop a system of indicators that most accurately characterize the energy saving techniques and their generalizations.

We offer to assess the level of achievement of goals and objectives in the field of energy conservation by using the system of indicators that can be conditionally divided into the cost, structure and relative groups. The analysis showed that such relative indicators as electricity consumption per capita, consumption of water per capita, consumption of natural gas per square meter and consumption of thermal energy per square meter most adequately reflect the energy saving and meet the requirements of objectivity, validity, reliability.

In order to summarize these indicators we have proposed an integrated assessment of the efficiency of energy use.

We suggest to determine the efficiency of energy use on the basis of comparison of achieved energy savings and the corresponding budget spending on energy conservation.

We propose to assess the performance of energy sources use as a measure of the closeness of the actual level of energy use to their normative values. It is assumed that the smaller the deviation of the actual value from the standard, the higher the performance of energy sources use. Integral assessment performance of energy sources use is defined as the weighted average of the percentage of deviation of the specific value of the actual use of energy source from its standard value.

\section{References}

Andersen, B. (2007). The Impact of Renewables and Energy Efficiency on Greenhouse Gas Emissions (p. 102). Copenhagen: Nordic Council of Ministers.

Anderson, V. (2005). Energy Efficiency Policies (p. 112). London, New York: Routledge.

Austria: IAEA. (2005). International atomic energy agency, United Nations department of economic and social affairs, International energy agency, Eurostat and European environment agency. Energy Indicators for Sustainable Development: Guidelines and Methodologies. Retrieved from http://www-pub.iaea.org/MTCD/ publications/ PDF/ Pub1222_web.pdf

Azmitov, R. R., Ivanovskiy, I. A., \& Korabelnikova, L. L. (2014). Features of Russian Companies Real Estate Appraisal in the Accounting System. Mediterranean Journal of Social Sciences, 5(24), 242-245.

Bashmakov, I. A. (2009). Improving energy sources use in public-sector organizations Energy Saving. Retrieved from http://www.abok.ru/for_spec/articles.php?nid=4404

Bhaskar, B. (2013). Energy Security and Economic Development in India: a holistic approach (p. 376). New Delhi: TERI. 
Burganova, R. A., Novak, V. V., \& Salahieva, M. F. (n. d.). Analysis of Using Capital Asset Pricing Model for Assessing Companies Return. Mediterranean Journal of Social Sciences, 5(24), 246-250.

Che, N., \& Pham, P. (n. d.). Economic analysis of end-use energy intensity in Australia. Retrieved from $\mathrm{http} / /$ bree.gov.au/publications/economic-analysis-end-use-energy-intensity-australia

Dudzevičiūtè, G. (2013). The research of the economic structural changes: energy consumption aspect. Journal of Security and Sustainability Issues Volume, 2(4), 13-23. http://dx.doi.org/10.9770/jssi.2013.2.4(2)

Gicquel, R., \& Gicquel, M. (2013). Introduction to Global Energy Issues (2nd ed., p. 252). Paris: Presses des Mines. http://dx.doi.org/10.1201/b15346

Government Printing Office. (2005). Congressional Record, V. 147, Pt. 7, May 22, 2001 to June 112001 (p. 1489).

Hu, W. (2011). With Post-Its and Checklists, Schools Cut Their Energy Bills. The New York Times. Retrieved from http://www.nytimes.com/2011/08/15/education/15energy.html

International Energy Outlook 2013 with Projections to 2040. Retrieved from http://www.eia.gov/forecasts/aeo/pdf/0383(2014).pdf

Kaswan, N. R. (1992). Energy Resources and Economic Development: A Study of Rajasthan (p. 182). New Delhi: Concept Publishing Company.

Lin, X. (1996). China's Energy Strategy: Economic Structure, Technological Choices, and Energy Consumption (p. 203). Connecticut: Greenwood Publishing Group.

Suehiro, S. (2007). Energy Intensity of a GDP as an Index of Energy Conservation (pp. 1-18). Japan: IEEJ.

Yakupova, N. M. (2013). Strategic management of enterprise value (p. 223). Kazan, Kazan University.

Yakupova, N. M., \& Absalyamova, S. G. (2014). Assessment and management of enterprise value. SGEM Conference on Political sciences, Law, Finance, Economics and Tourism 2014. Conference proceedings, (Vol. IV, pp. 51-58). Albena, Bulgaria. http://dx.doi.org/10.5593/sgemsocial2014/B24/S7.007

\section{Copyrights}

Copyright for this article is retained by the author(s), with first publication rights granted to the journal.

This is an open-access article distributed under the terms and conditions of the Creative Commons Attribution license (http://creativecommons.org/licenses/by/3.0/). 